UNITED STATES DEPARTMENT OF THE INTERIOR

J. A. Krug, Secretary

GEOLOGICAL SURVEY

W. E. Wrather, Director

\title{
Bulletin 953-B
}

\section{MANGANESE DEPOSITS OF THE REPUBLIC OF HAITI}

BY

\author{
E. N. Goddard, L. S. Gardner, and W. S. Burbank
}

Geologic Investigations in the American Republics, 1945

(Pages 27-52)

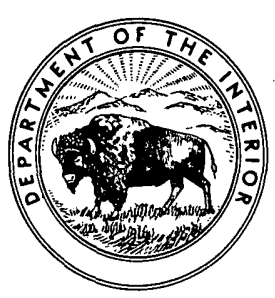

UNITED STATES

GOVERNMENT PRINTING OFFICE

WASHINGTON : 1947

For sale by the Superintendent of Documents, U. S. Government Printing Office, Washington 25. D. C. Price 15 cents 
Manganese deposits of the Republic of Hait1, by E. N.

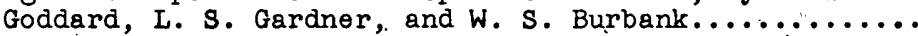

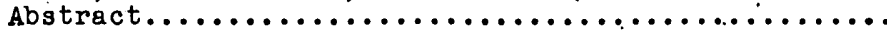

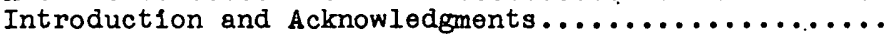
Manganese deposit at Morne Macaque, near Gros Morne,

Republic of Hait1, by E. N. Goddard and L. S. Gardner..

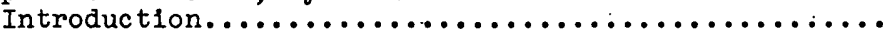

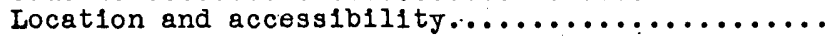
Labor and transportation.................

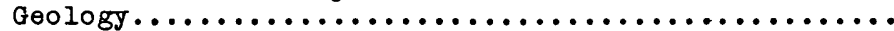

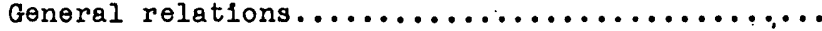

Local geology............................. structure and character of the fault......... Manganese deposit..........................

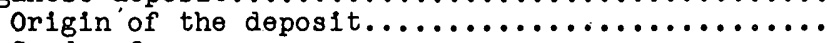

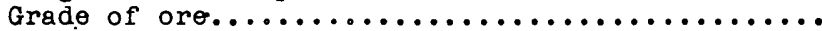

Reserves................................

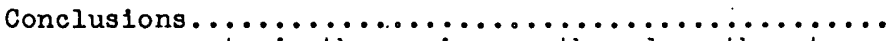

Manganese prospects in the region north and northwest

of Jacmel, by. E. N. Goddard and L. S. Gardner.........

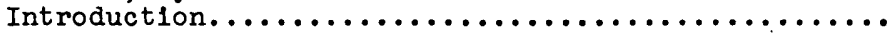

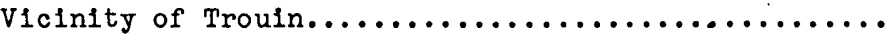

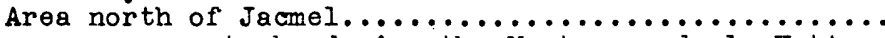

Manganese prospects bordering the Montagnes de la Hotte,

by w. s. Burbank...........................

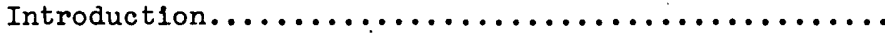

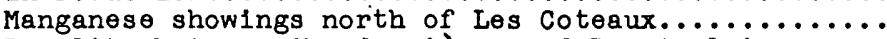

Locality between Chardonnierres and Les Angla1s.......

Localities erst of Anse d'Halnault................

General conclusions on the orlgin of the manganese

and Jasper' in the Southern Peninsula, by W. S.

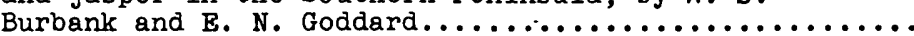

\section{ILLUSTRATIONS}

Plate 10. Index map of the Republic of Ha1t1..........

11. A, Photograph of Morne Macaque, looking south from a low divide. Manganese deposit is on hill at left; $\underline{B}$, specimen from trench No. 2, showing oligocene limestone enclosing brecclated manganese oxides.............................

12. Geologic maps and sections of the east slope of Morne Macaque, near Gros Morne, Republic of Ha1t1.................... 
Plate 13. Outcrops of silicejous manganese vein

(black bayate), Morne Macaque manganese deposit. $A$, Fifty-ton' boulder at head of trench Ǹ․ 1 ; $B$, Outcrop at head of trench No. $2 \ldots \ldots \ldots \ldots \ldots \ldots \ldots \ldots \ldots \ldots \ldots \ldots \ldots$

14. Cross sections of the manganese vein

exposed in trenches, Morne Macaque manganese deposit; near Gros Morne,

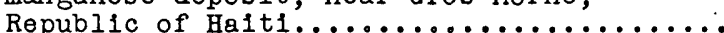

Figure 3. Index map of the region between Gonalves and Gros Morne, Republic of Hait1, showing location of the Morne Macaque

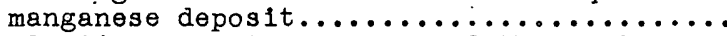

4. Geologic reconnalssance map of the region between Port-au-Prince and Jacmel, Département de l'ouest, Republic of Hait1..

\section{TABLES}

Page

Table 3. Analyses of manganese ore from the Morne.

Macaque manganese deposit.............. 
MANGANESE DEPOSITS OF THE REPUBLIC OF HAITI

By E. N. Goddard, L. S. Gardner, and W. S. Burbank

ABSTRACT

The manganese deposits of the Republic of Halt1 were studied by the U. S. Geological survey during the winter of 1941-42 in connection with strategic mineral investigations. Early reconnalssance work showed that three widely scattered areas merited further study: (1) the area near aros Morne in northwestern Ha1t1; (2) the region north and northwest of Jacmel in the eastern part of the Southern Peninsula; and (3) the reglon borderling the Montagnes de la Hotte in the western part of the Southern Peninsula.

On the east slope of Morne Macaque, about $4 \frac{1}{2}$ miles south of Gros Morne, is a small manganese deposit that merlts further exploration. It is associated with a strong northwest-trending fault more than 15 miles long whlch forms the west side of an extensive graben block. On the west side the fault is a thick series of volcanic rocks of Cretaceous (?) age capped by Eocene conglomerate and limestone. On the east side is Oligocene (?) limestone grading eastward into undoubted oligocene clays, marls and limestones. These beds dip steeply to moderately nor theast. The manganese deposit occurs in the fault zone associated with a large lenticular body of black, brown, and yellow jasper, called "bayate" In Cuba. Th1s bayate body is about 800 feet long, has a maximum width of 25 feet, and stands up in prominent outcrops. The black bayate is intimately banded with seams and lenses of manganese oxide; on the east side of the zone.1s an irregular pockety vein of rather high grade manganese ore from 1 to 6 feet wide and possibly as much as 15 feet wide. The vein is composed of a mixture of pyrolusite, manganite, and some wad. On the west side of the black bayate zone there is a narrow vein of manganese oxides a few inches to 18 inches wide. Only small amounts of the manganese oxides are assoclated with other bodies of bayate in this area.

Avallable evidence seems to indicate that the deposit had a similar origin to those of Cuba; the manganese oxides and assoc1ated bayate were apparently deposited contemporaneously with the adjacent limestones and were dragged up along the fault. However, there was considerable reworking of both menganese and silica by waters circulating along the fault plane. On the basis of exposures in and samples taken from exploratory trenches, it is estimated that the deposit contains 6,000 tons of indicated (probable) ore averaging 40 percent of manganese and about 33,750 tons of highly siliceous ore averaging 20 or 25 percent of manganese. 
In the eastern part of the Southern Peningula, 6 to $12 \mathrm{miles}$ north and northwest of Jacmel, there are a number of localities where small amounts of manganese oxides are associated with brown to yellow jasper or bayate. Some of these bayate bodies are along the contact of a large body of Cretaceous basalt with upper Eocene limestone; others are assoclated with limestones interlayered with the basalt. In some localitites, boulders of this bayate have accumulated on slopes or in valleys, but no bayate can be found in place. In all these localities, the showing of manganese oxides is so poor that further prospecting seems unwarranted.

In the western part of the Southern Peninsula, a little man- ganese oxide was found in two places, one north of Les coteaux on the south coast, and one about 4 miles east of Anse d'Hainault. At the former, smail nodules and pellets of manganese oxides are associated with calcareous tuff and breccia in basalt, and at the latter a small vein of manganese oxide a few inches wide is exposed near the contact of basalt with kaolinized porphyry. Neither of these deposits contain enough manganese to warrant further prospecting.

\section{INTRODUCTION AND ACKNOWLEDGMENTS}

As a result of conversations between the President of the United States and the President of the Republic of Haiti, discussions were initiated in May 1941, between the Department of State and the Department of the Interior to make a survey of the strategic mineral resources of the Republic of Hait1. The Geological survey was designated by the secretary of the Interior to undertake this work. Plans for the survey were approved in August 1941 and funds were made avallable from the general defense funds of the President. Members of the Survey party arrived in Port-au-Prince in late November 1941, and field work was concluded the latter part of March 1942.

The survey was primarily almed at a search for commercial deposits of manganese, chromium, and nickel, as these metals were known to occur in the mineral deposits of the island. Small deposits of manganese, similar in some respects to those of Cuba, were known in the Republic of Haitl as a result of reconnalssance surveys made in 1921 and 1922, and therefore special attention was given to a study of the manganese deposits. No large deposits were found, but one small deposit and several mineralogic occurences were investigated. Because of the general geologic interest of the deposits, and because of their similarity to the highly productive deposits of Cuba, the descriptions of the principal occurences examined are pubilshed here in advance of the results of other work.

The President of the Republic of Halti made available all facilities of the Government that might aid in the work, and designated Mr. Max Mangonès, mining engineer under the secretary of State for Public Works, as a special representative of the Government on the survey. Special acknowledgment is due Mr. Mangonès for his invaluable ald in the fleld. The Minister of Public Works, Mr. Francols Georges, the Engineer Director of Public Works, Mr. Robert Covington, and engineers in the field departments furnished ald and equipment in exploratory work. The Garde d'Haiti greatly aided in supplying quarters, guides and means of transportation. 
MANGANESE DEPOSIT AT MORNE MACAQUE, NEAR GROS MORNE, REPUBLIC OF HAITI ,

By E. N. Goddard and L. S. Gardner

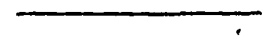

\section{INTRODUCTION}

At Morne Macaque, about $4 \frac{1}{2}$ miles south of Gros Morne, in the Republic of Hait1, is a small manganese deposit that deserves further exploration, although as yet it bears little promise of yielding large quantities of ore. It is located on an extensive fault that can be traced for many miles, but a diligent search of the region falled to reveal any other manganese deposits along this fault. Much of the ore is of low grade and highly siliceous, but some is of high grade; possibly several thousand tons of ore contalning 40 percent of manganese could be mined at low cost. A number of transportation difficulties must be overcome, however, if the ore is to be handled economically.

Apart from 1ts economic possibilities, the Morne Macaque deposit has some very interesting geological features, and in some respects it resembles the much more extensive and economically important manganese deposits in Cuba. For this reason a rather detalled description of the deposit and a brief discussion of its origin seem justified.

The Morne Macaque deposit was first examined and described by J. S. Brown and W. S. Burbank, who visited the locality in the spring of 1921 while they were engaged in a geological survey of Hait1 for the Department of Public Works.1/ During that examination no attempt/was made to trench or expose the deposit to est1mate grade and tonnage, but it was concluded that the ore exposed at the outcrop was mostly too siliceous to be salable in the current market. Since then no development work appears to have been done on the deposit.

In connection with the strategic mineral survey of. Haits in the winter of 1941-42, the writers visited the deposit with $W . s$. Burbank, W. P. Woodring, and Max Mangonès. As a result of this visit, it was decided that the deposit should be mapped in detall, topographically and geologically and explored by trenching. The writers spent about a month on this project in January and March 1942. Mr. Mangonès, a mining engineer of the office of Public Works, rendered valuable assistance, especially in supervising the trenching of the deposit, and Mr. San Lo, district engineer of Public Works at Gonalves, furnished estimates of road construction costs and alded the narty in procuring laborers and materials.

I/ Woodring, W. P., Brown, J. S., and Burbenk, W. S., Geology of the Republic of Hait1, pp. 470-475 (Prench edition, pp. 530-536): Republic or Heit1, Dept. of Public Norks, Port-au-Prince, 1924. 


\section{Location and accessibility}

$\circ$

The manganese deposit lies at an altitude of about 1,000 feet, on the east slope of Morne Macaque, about $4 \frac{1}{2}$ miles south of Gros Morne and 12 miles north of Gonaives, in the Département de l'Artibonite (see pls. 10, 11 , and fig. 3 ).

Gonalves, a town of about 12,000 people, is the nearest port. It has a good harbor and is a port of call for ocean frelghters, but has no dock-loading facilities for such frelghters, and all commodities must be carried from wharf to ship in lighters. Gros Morne, a town of about 1,000 people or more, is on the main road between Gonalves and Port de Paix. This road is gravel-surfaced and passes within about 2 miles of Morne Macaque. The manganese deposit is only about 1,100 feet from the old abandoned Gonalves-Gros Morne road of 1921, which has been completely washed out by heavy rains. A small amount of repalr work by the Office of Public Works of Hait1 on $3 \frac{1}{2}$ miles of the northern part of this old road enabled the writers to drive within about 4,500 feet of the deposit, but even this section of road is impassable during the rainy season. The practicability of repalring the old road or of building a new one is Aiscussed below.

\section{Labor and transportation}

The small size of the manganese deposit makes it uneconomic to expend a large sum of money on mining and milling equipment or on building roads. The low cost of labor in Haiti, however, makes it possible to mine ore cheaply by hand drililing and hand sorting. In 1942 common laborers could be procured in abundance at the rate of 30 cents (J. S. currency) a day, and foremen at $\$ 0.80$ to $\$ 1.20$ per day. The ore could be mined by open-pit methods to a depth of about 50 feet by common laborers. At greater depth underground methods would probably have to be used, for which trained miners would be needed; and only a few such miners are avaliable in the Republic.

Among the problems to be solved in exploiting the Morne Macaque deposit is that of transportation by land and sea.

In order to make the deposit accessible for trucking throughout the year, an entirely new road would have to be constructed from the Gonaives-Gros Morne road to the deposit, at a cost, as estimated by the Office of Public Works of Hait1, of approximately $\$ 15,000$. The old road, which approaches Morne Macaque from the northeast, could be put in condition for Truck transportation during the dry season at a cost of about $\$ 2,000$, but it would be impassable during the rainy season. It might be feasible, if the deposit were worked, to stockpile the ore at the mine during the rainy season and haul it only during the dry season. This appears to be the only practicable plan until development has proved larger reserves of ore. The total distance by this route from the deposit to the wharf at Gonalves is about 21 miles. 


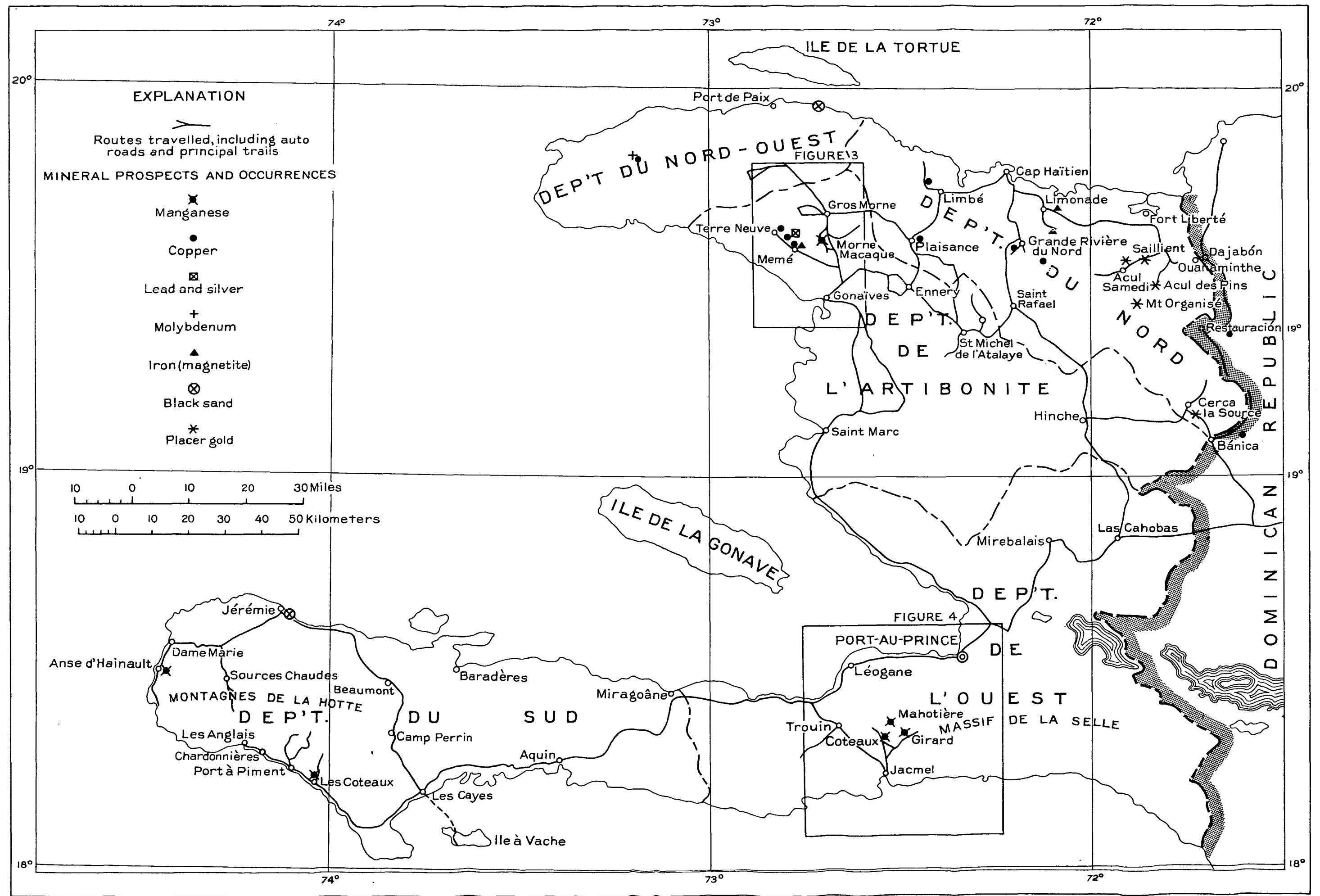




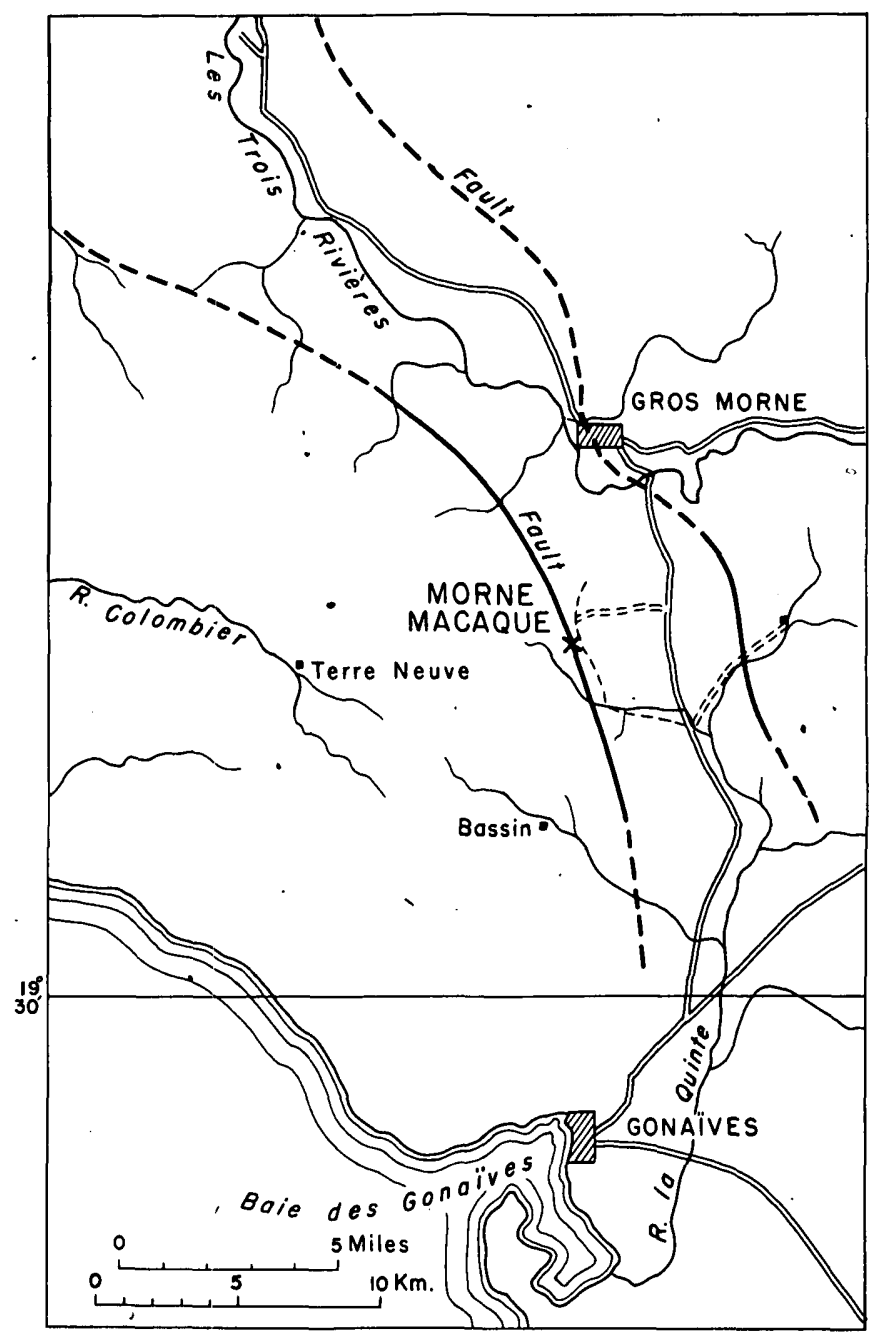

Figure 3.-Index map of the region between conalves and Gros Morne, Republic of Halti $7368410-47-2$ 
If ore were shipped from Gonalves, it would have to be moved by lighter from wharf to ship. Manganese ore, if not too powdery, could be transferred in this manner by hand shovelling. Sacking the ore would add greatly to the expense. Shipping charges to the Atlantic seaboard on small lots ( 400 tons. or more) of ore handled in this way would probably be in the nelghborhood of $\$ 12.00$ per ton, including wharfage and lightering charges. At Port-au-Prince, the ships are loaded at the dock, but that port has no facilities for handling bulk ore, and the truck baul to Port-au-Prince would be long and costly. It seems likely that the only feasible means of. ocean transportation would be small frelghters of 700-' or 800-ton capacity, or small salling vessels that would call at Gonalves and carry only manganese ore.

\section{GEOLOGY}

\section{General relations}

Morne Macaque is part of a low northwest-trending mountain range on the west side of the structural valley that separates the Massif du Nord on the east from the Northwest Peninsula on the west. The manganese deposit is assoclated with a strong northwest-trending fault, which extends for more than $15 \mathrm{miles}$ along this range and forms the west side of an extensive graben block; 15 to $25 \mathrm{miles}$ long and 3 to 8 miles wide (see flg. 3 ). The block is marked by a topographlc depression, the northern part of which is the valley of Les Trois Rivieres, and the southern part the valley of Rivière la Quinte.

This block is composed of interbedded Iimestone, marls and grits of oligocene age, which have been warped into a series of folds paraliel to the trend of the block. On either side of the graben is a thick accumulation of volcanic rocks, probably Cretaceous, interbedded with some thin limestone beds and overlain by Eocene conglomerate and limestone.

\section{Local geology}

The relations of the geology of Morne Macaque to the regional geology are well shown on a map by Brown and Burbank, 2/ and the local geology is shown on plate 12 .

On the west side of the fault is a thick series of volcanic rocks, represented on Morne Macaque by andesite and andesite breccla. The breccla, which is next to the fault, seems to grade westward and upward into coarse andesite conglomerate, but the exact relations between. the two are masked by erosion and float. The upper slopes of Morne Macaque are covered with andesite boulders belonging to this conglomerate, but the cementing mater1al is rarely seen. The bedding in the conglomerate is obscure; its attitude could be observed at only one place on a southeast ridge of Morne Macaque, where 1 t strikes N. $20^{\circ}$ E. and dips $42^{\circ}$. At two places on Morne Macaque (se日 pl. 12), small remnants of a

2/ Woodring, W. P., and others, op. cit., pl. 2. 


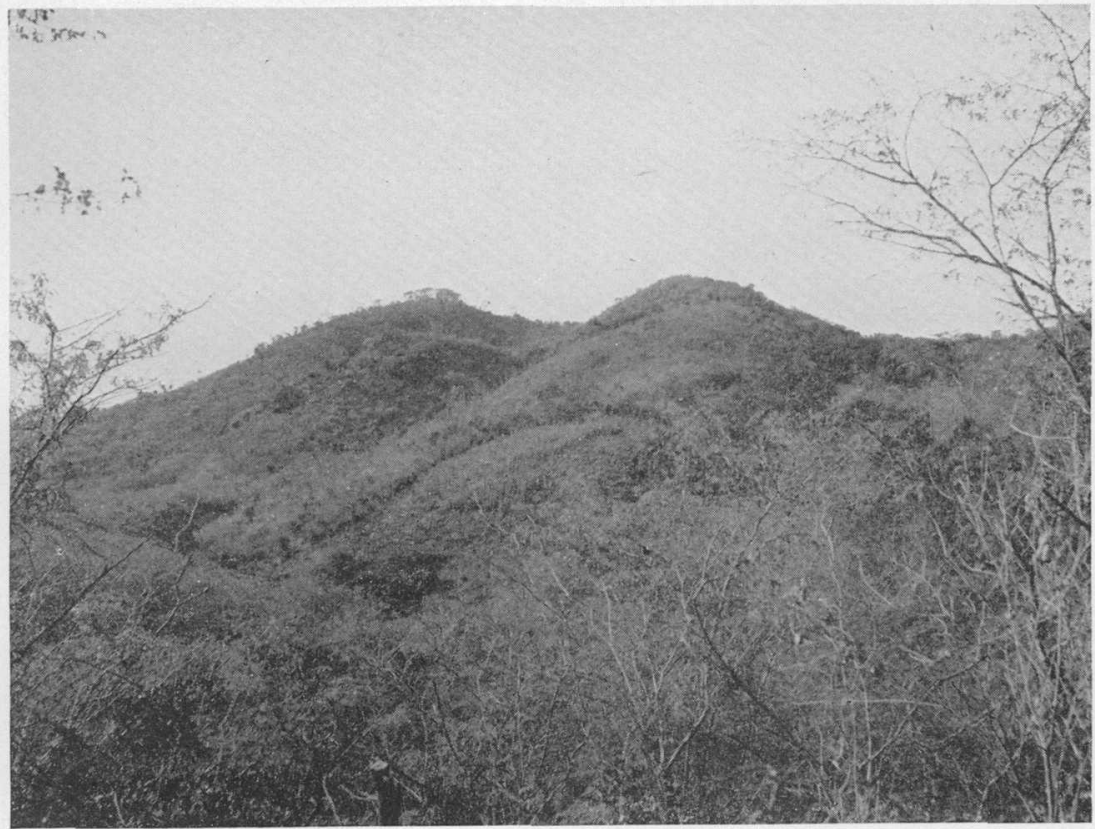

A. PHOTOGRAPH OF MORNE MACAQUE, LOOKING SOUTH FROM A LOW DIVIDE. Manganese deposit is on hill at left.

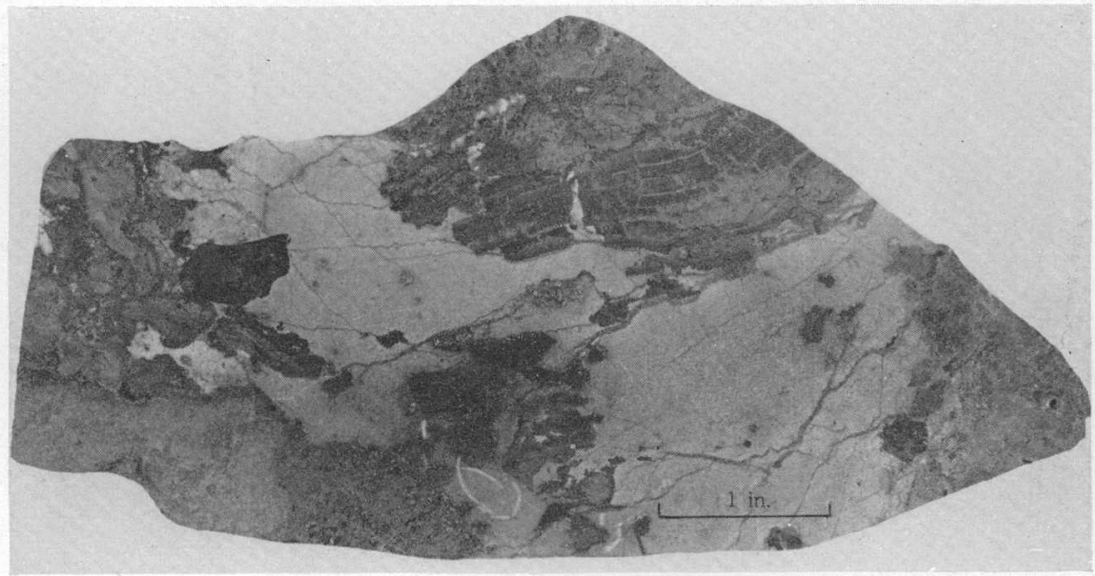

B. SPECIMEN FROM TRENCH NO, 2.

Oligocene limestone enclosing brecciated manganese oxides. 
dense, thin-bedded white limestone of Eocene age lie on the conglomerate and volcanic rocks and dip $32^{\circ}-50^{\circ} \mathrm{NE}$. At its base this limestone has a greenish color and contalns small pebbles of volcanic rocks. Foraminifera collected from the limestone on Morne Macaque by Brown in 1921 were ldentified by Woodring $3 /$ as of Eocene age.

On the east side of the fault, occupying the middle and lower eastern slopes of Morne Macaque, there is also a dense, white, thin-bedded IImestone, very similar to the Eocene Iimestone on the west side of the fault. Where this rock has been dragged up along the fault zone, it strikes $\mathrm{N}$. $10^{\circ}-68^{\circ} \mathrm{W}$, and dip. $62^{\circ}-80^{\circ}$ NE., but 500 to 600 feet farther east its dip gradually flattens to $25^{\circ}-40^{\circ} \mathrm{NE}$. The lower eastern slopes of Morne Macaque and the valley at its base are largely covered with float. and alluvium, but in the valley bottom a short distance to the north, clays and marls containing interbedded limestones are exposed, whlch have been Identified by Woodring 4 / as upper oligocene.

During the present investigation Woodring also collected some upper oligocene Foraminifera from limestone about $2 \mathrm{miles}$ southeast of Morne Macaque and about half a mile east of the fault. The thin-bedded white limestone adjoining the fault on Morne Macaque has not been traced continuously to the undoubted 0ligocene beds in the valley; there is consequently some doubt as to its age, but it also is here tentatively dated as upper oligocene, as was done by Burbank and Brown. 5

Structure and character of the fault. - The general trend of the fault along the east slope of Morne Macaque is N. $30^{\circ} \mathrm{W}$., but its trace is very irregular in places (see fig. 3). Its dip appears to be steep everywhere, and along the manganese deposit it ranges from $70^{\circ} \mathrm{E}$. to vertical. The fault is nowhere well exposed on Morne Macaque. An exposure about half a mile to the north 1s marked by about 40 feet of sheared limestone, but in other places the fault zone appears to'be only a few feet wide. On Morne Macaque, near the silicified rock or jasper that occupies part of the fault zone, the limestone bordering the jasper is sheared in places for a width of half an inch to 6 inches, and the jasper itself is generally sheared or crushed by movement along the fault. The downthrow is on the east, and is est1mated by Burbank and Brown 6/ as "....probably at least 500 meters $(1,640$ feet), possibly much more." This estimate is based on the assumption that the limestone just east of the fault is oligocene and is underlain by the Eocene rocks that are exposed, and deeply eroded, on the west side of the fault. It 1s barely possible, however, that the limestone on the east side is partiy of Eocene age, in which case the displacement might be only a few hundred feet.

There are few grooves on the walls of the fault, and they give no adequate indication as to direction of movement; but the irregularities of the fault seem to require. that the displacement was nearly stralght down the dip, for any appreciable horlzontal movement would have produced strong brecciation at places

3/ Woodring, W. P., and others, op. c1t., p. 141, and tablo opposite p. 144.

4 Idom, pp. 151-152.

$5 /$ Idem, p. 470.

6/ Idem, p. 471 . 
where the strike of the fault abruptly changes. In a few places the jasper in the fault zone is marked with small grooves that pitch about $20^{\circ} \mathrm{N}$. , but these grooves are probably due to minor movement later rather than the major faulting.

\section{MANGANESE DEPOSIT}

The manganese ore of the Morne Macaque deposit occurs in the fault zone. It is assoclated with large lenticular bodies of brown and yellow or black jasper, chalcedony, and quartz. The chlef ore minerals are pyrolusite and manganite, which are. largely intergrown with the chalcedony and quartz. Sillceous material practically identical with that on Morne Macaque is associated with manganese deposits in Cuba,7/ where the miners call it "bayate," and this name will therefore be used in describing the Morne Macaque deposit.

As shown on plate 12, there are two distinct lenticular bodies or veins of bayate along the fault zone, one on the east slope of Morne Macaque and one on a prominent spur to the north. These bodies range in width from a few feet to 50 feet, and the slopes below the outcrops are covered with bayate rubble, including some huge boulders. On the east slope of the mountain, many of the boulders line up in a northwesteriy direction, roughly paraliel to the fault zone, and some of these seem to be nearly in place and to represent other bayate zones. Their structural relations are discussed on page 36. Five hundred feet east of the fault.is a zone of bayate, obviously in place, that is somewhat different from the rest. The outcrops indicate a body about 180 feet wide and 480 feet along, which appears to have no connection with any fault or other structural break. This bayate is mostly yellow but partiy red, and apparently contains no manganese whatever. It seems to line up roughly with the bayate zone along the fault on the north spur.

Nearly all the manganese ore is found in the more southerly of the bayate zones along the fault. Here bajate can be traced more or less continuously for a length of 800 feet, and through a maximum width of 25 feet. The ends of this zone are composed of brown bayate containing little manganese oxide, but the central part is a lenticular body, about 275 feet long, of black bayate containing much manganese oxide (see pls. 12. and 13). at the north end of this zone is a disconnected segment of bayate about.75 feet long, which appears to extend out into the andesite breccia. This segment may have been broken off from the main zone by a cross fault, or may have filled a branch fissure of the main fault zone.

Nearly all the manganese ore of the Morne Macaque deposit is associated with the black bayate, which stands up in prominent boulderlike outcrops 6 to 20 feet high. The black color of this. beyate seems to be due to a microscopic intergrowth of quartz or chalcedony, or both, with manganese oxides. The black bayate is intimately banded with seams and lenses of pyrolusite. and manganite from a fraction of an inch to several inches wide. In places this material grades into irregular pockets of relatively high grede manganese ore, well represented by a 50-ton boulder at the head of trench No. I (see pl, $13 \mathrm{~A}$ ).

I/ Burchard, E. F., Kanganese ore deposits in Cuba: Am. Inst. Min. Met. Eng. Trans., vol. 63, pp. 51-104, 1919. Park, C. P., oral communication. 

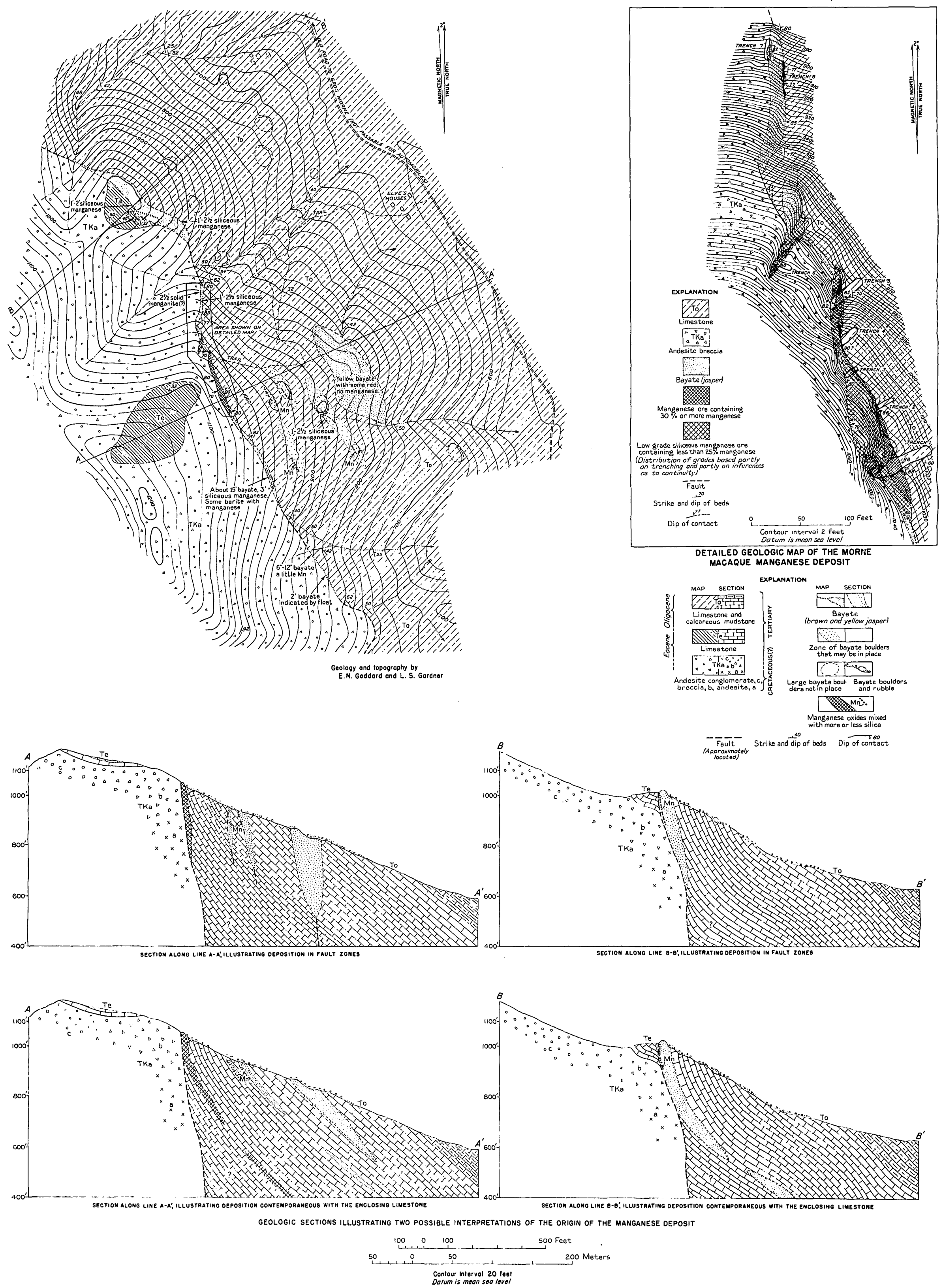
On the east side of the black bayate zone is an irregular pockety vein of relatively high grade manganese ore, ranging in width from 1 foot to at least 6 feet and possibly as much as 15 feet (see pl. 12). This vein is chiefly composed of a mixture of pyrolusite, manganite, and some wad; it contains only a little silica. In places it seems to grade into the black bayate zone. The vein. is bordered on the east by a nearly vertical wall of limestone that has been dragged up along the fault. The contact is marked by a thin selvage of sheared limestone and manjanese oxides, and the limestone is commonly pinkish for a few feet from the vein. In places this pinkish limestone contains small lenses of manganese oxide a few feet in length, which penetrate the Ilmestone irregularly but are generally parallel to the bedding. Scattered through some of these lenses and in the adjacent. Ilmestone, are small grains of a greenish-yellow waxy mineral which has been identified by Jewell JoGlass, of the United States Geological Survey, as a clay mineral, probably nontronite.

Along the west side of the black bayate zone, there is in most places a narrow vein of manganese oxides from a few inches to 1.8 inches wide, and veinlets of the oxides extend irregularly from the black bayate body for as much as 3 to 5 feet into more or less shattered and altered andesite breccia.

Origin of the deposit. - The structural features of the Morne Macaque manganese deposit and the mode. of occurrence of the manganese oxides heve two possible interpretations, both of which are illustrated in the sections in plate 12.

The occurrence of the bayate and manganese minerals in a fault zone might naturally lead to the assumption that these materials were deposited in the fault zone, either by hot or cold ascending solutions or by cold descending solutions. Burbank 8/ came to the conclusion that "it is ... probable that the deposits were formed by hot spring waters associated with igneous activity of Mlocene or later age..." But a restudy of the deposit, and its exploration by trenching, have brought to light certain similarities to some of the Cuban deposits that point to a different conclusion. It now seems probable that the manganese and bayate are bedded deposits, contemporaneous with the limestone with which they are in contact, and that they have been turned up along the fault, though some waters circulating along the fault may subsequently have caused redistribution and recrystallization of the manganese oxides.

In the Cuban deposits, 9 / manganese oxides and associated masses of bayate are interbedded with limestones and tuffs of Eocene age. The bayate is in the form of irregular or lenticular masses, from which the manganese ore commonly extends outward along the bedding of the strata. According to Park,10/ "most of the manganese deposits are bordered or overlain by red tuffs and limestones..." Park $11 /$ concluded that the manganese was derived from warm springs. He says: "it is belleved

8/ Woodring, W. P., and others., op. cit., p. 47 .

9/ Burchard, E. F., op. c1t.

Park, C. I., Jr., Manganese deposits of Cuba: D. S. Geol: Survey

Bul1. 935-B, pp. 75-97, 1942.

$10 /$ Park, C. I., Jr., op. c1t., p. 83.

II) Idem, p. 93 . 
that the warm waters rising along condults deposited manganese oxides at favorable places along the condults and in adjacent porous beds, partly by direct deposition in openings and partly by replacement of tuff or limestone; it is also belleved that warm water reaching the sea deposited manganese oxides as a primary sediment."

Certain features of the Morne Macaque deposit indicate that much of the high-grade manganese ore was likewise deposited as a primary sediment. Where exposed in trenches 2 and 4 (see pl. 14), the limestone within 3 to 6 feet of its contact with the high-grade manganese vein is pink and contalns small lent1cular bodies of manganese oxides, which appear to be contemporaneous with the enclosing limestone. The boundaries of these lenses are roughly paraliel to the beding but are partly broken; small fragments of manganese oxide are scattered through the limestone, and small seams of limestone penetrate some of the larger lenticular bodies (see pl.11B). Many of the fragments are angular, but some are bordered on one or more sides by a fine reniform structure, which suggests that they were torn from the crust of a manganese layer deposited in an open space, possibly as a layer in a surface spring deposit. As seen in thin section, the limestone contains numerous globigerina, and some of these particularly near the reniform bodies, are enclosed in the manganese oxide. Minute pellets of yellow clay, probably nontronite, also are found in the manganese oxide and in a few Inches of the adjacent limestone. It seems likely that these brecclated manganese lenses are derived from a thin layer of manganese oxide which was deposited on the sea floor, subsequentiy broken up by wave action, and covered with calcareous sediment. There is no evidence of brecciation of the limestone, though it and the enclosed manganese oxides are cut by undulating seams of calcite.

other evidence partly confirms this view, though the relations are considerably obscured by surface debris. Nowhere, even in the deepest trenches, could the black bayate be found in direct unfaulted contact with either the limestone or the andesite breccla; the large masses of bayate on the slopes are in the form of boulders, and although some of these must be nearly in place, thelr contacts are thoroughly obscured by a thick cover of rubble and talus. The bayate bodies lying east of and downhill from the manganese deposit are difficult to explain, however, as being localized along subsidiary faults and fissures. In the surrounding limestone, which is exposed here and there on the slopes and in the sharp ravines, no ev1dence is to be seen of mineralized fissures or faults alined with the lenticular bayate bodies. Furthermore, masses and boulder trains of bayate exhibit physiographic relations that are consistent with derivation from east-dipping bedded deposits rather than from vertical masses along fissures (see pl. 12). They are in exact alinement with the strike of the bedding, and where they are exposed in the trenches their dips conform to those of the nearby limestone beds. It may also be pointed out that the lower bayate mass on the slope of the south bill is at approximately the same stratigraphic horizon as the large mass on the north hill adjacent to the fault.

An origin essentially contemporaneous with the sedimentary rocks also accounts satisfactorily for certain reglonal features of the bayate occurrences in Baiti whose meaning would be otherwise obscure. The lack of such deposits elsewhere along the fault contact for many miles can thus be accounted for on the supposition that the deposits were formed only in narrow belts 


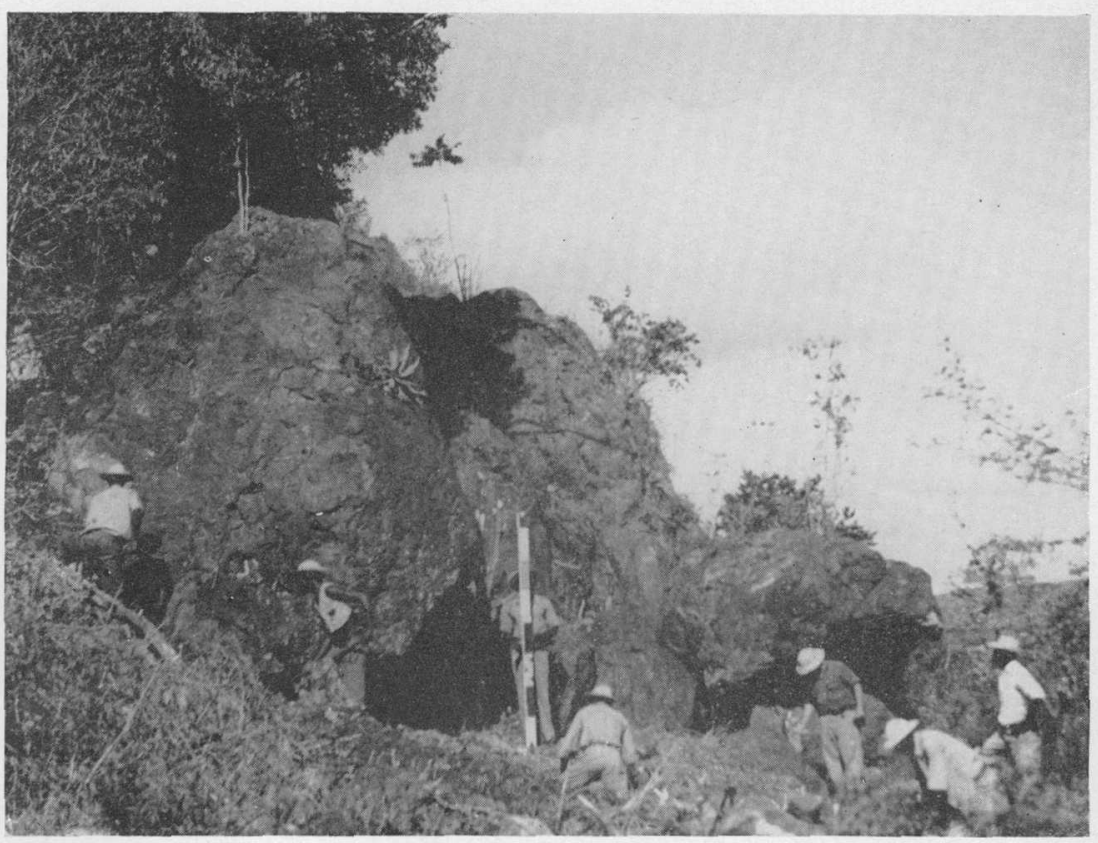

A. FIFTY-TON BOULDER AT HEAD OF TRENCH NO. 1.

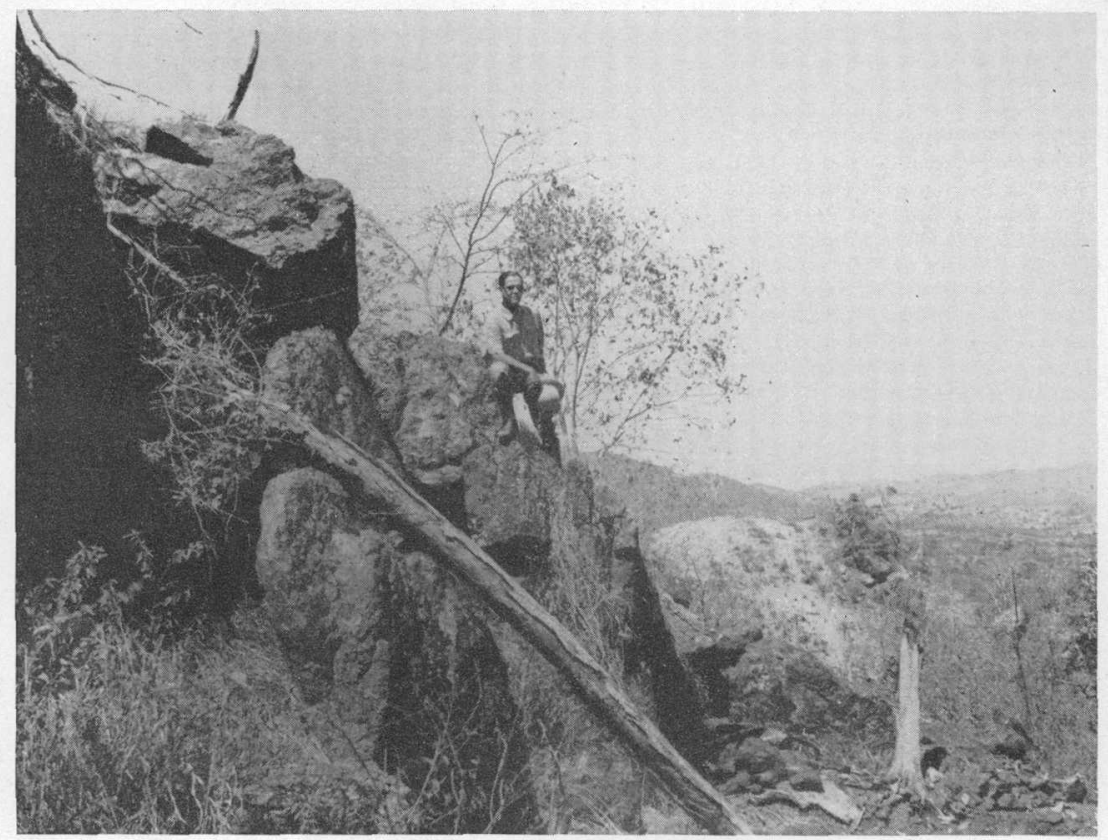

B. OUTCROP AT HEAD OF TRENCH NO. 2.

OUTCROPS OF SILICEOUS MANGANESE VEIN (BLACK BAYATE), MORNE MACAQUE MANGANESE DEPOSIT. 
on the sea floor, with a trend somewhat oblique to that of the feult. The distribution of the bayate in the limestones, tuffs, and basalts of the Southern Peninsula north of Jacmel also is more in accordance with this view than with one that attributes the localization of the deposits to structure alone.

Because of the evidence discussed above, the writers are inclined to belleve that the manganese deposit at Morne Macaque, and the associated bayate, were deposited on the sea floor by warm springs and are virtually contemporaneous with the adjacent IImestone. If that is true, these materials were dragged into their present position by later faulting and their association with the fault.1s largely fortuitous. However, there is evidence of considerable reworking of both manganese and silica by waters, probably of meteoric orlgin, that circulated along the fault plane. It must be admitted that this explanation of the manganese deposits cannot be proved from the evidence at hand but it is consistent with the known facts and is in agreement with conditions that obtain in large areas in the neighboring island of Cuba. If development work at the deposit is undertaken, it should be planned with a view to testing the relations of the manganese layers to the limestone bedding at depth.

\section{Grade of ore}

Most of the manganiferous material exposed in the Morne Macaque deposit is of low grade and highly siliceous, but a small tonnage of good manganese ore has been exposed by trenching; it is possible that there is enough of this material to constitute minable bodies of ore. The black bayate, which is mainly a mixture of chalcedony and manganese oxides, is exposed over a total length of about 300 feet and has an average width of about 15 feet. A sample cut by the writers across 17 feet of this sil1ceous material contained 22.92 percent of manganese, 54.33 percent of silica, 0.05 percent of $\mathrm{P}_{2} \mathrm{O}_{5}$, and no sulfur:12/ Burbank 13 / cut a sample at approximately the same place across a width of 8 or 9 meters; this sample contained 25.8 percent of manganese, 1.52 percent of $\mathrm{Fe}_{2} \mathrm{O}_{3}$, and 0.028 percent of phosphorous. The writers believe that these two analyses give a fair Idea of the grade of the black bayate zone.

Very little manganese ore of good grade and low sllica content was exposed at the surface of the Morne Macaque deposit. except for the 50-ton boulder already mentioned. It was thought, however, that the presence of a zone of relatively soft, nonsiliceous manganese ore on the east side of the siliceous zone might be indicated by the pronounced bench along the east side of the black bayate zone (pl. 14). Flve trenches were dug, therefore, along the main zone of black bayate, and one on the small detached lens to the north. The location of these trenches is shown on plate 12 and cross sections of them on plate 14 . Bedrock was exposed in three of the trenches, and in all three a zone of ore relatively free from silica was found on the east side of the black bayate. In the other three trenches, boulders of ore almost in place were found, but bedrock was not reached,

$12 /$ Analysis by J. D. Falrchild, U. S. Geological Survey.

13/. Woodring, W. P., Brown, J. S., and Burbenk, W. S., op. c1t., p.475. 
because the bench is there underlain by a gravel-filled gully along the east side of the bayate zone. Apparently some of the soft manganese ore had been gouged out by a heavy rainfall and the resulting gully had been quickly filled with debris from the walls.

The ore in place in these trenches, and also that in boulders exposed in the other trenches, was carefully sampled. Analyses of the samples are given in table 3. The samples contained from 31 to 47.70 percent of manganese, from 7.87 to 31.51 percent of silica, from less than 0.01 to 0.15 percent of $\mathrm{P}_{2} \mathrm{O}_{5}$, and no sulfur. The most significant analyses are those of samples MM 29 and MM 30, which were taken where the vein was best exposed and contalned very little visible siliceous materlal. In the other samples, some visible siliceous material was mixed with the manganese, and no attempt was made to cob 1t out. By careful cobbing and sorting, it should be possible to produce ore containing 40 percent or more of manganese and 15 percent or less of silica. The ore from trenches Nos. 2 and 5 (samples MM 29 and MM 30) could not be sorted, for it contains no visible waste.

\section{RESERVES}

The Morne Macaque manganese deposit contains only a small tonnage of ore in sight and its total volume is not large. Lowgrade siliceous ore or black bayate is falrly well exposed over $a$ length of about 300 feet, an average width of $15 \mathrm{feet}$, and a vertical distance of 75 feet. If this siliceous ore extends to an average depth of 75 feet below the surface, as seems probable, and a verages 10 cubic feet to the ton, this siliceous block contains about 33,750 tons of indicated ore, which will probably average 20 or 25 percent of manganese and 50 percent of silica.

The better ore is softer and less well exposed than the sillceous material and appears to be more pockety. For the purpose of estimating reserves, however, it seems reasonable to regard this ore as forming a vein that borders the black bayate zone along its entire length (see pl. 12). The zone of good-grade soft ore on the east side of the black bayate zone is estimated to average about 3 feet in width. In trenching, the soft ore was exposed through a vertical distance of only 37 feet, but this is due to the fact that the ore is rather deeply eroded on the east side of the black bayate zone; it seems justifiable to. assume that the good ore extends to an average depth of 5.0 feet below its exposures in the trenches. The indicated ore of this character would thus form a block 300 feet long, 3 feet wide, and 50 feet deep. Assuming that this ore also will average about 10 cubic feet to the ton, its weight would be about 4,500 tons.

On the west wall of the black bayate zone, some good ore can be cobbed from the andesite breccla. This ore averages about 1 foot in width for the full length of the zone, and is exposed through a vertical distance of 50 feet. A block 300 feet long, 1 foot wide, and 50 feet deep would contain about 1,500 tons. This narrow zone could not be mined as cheaply as the wider zone on the east side.

The total indicated reserves of manganese ore averaging close to 40 percent manganese are thus estimated to be 6,000 tons. since this deposit is so limited in known extent, and since no other deposits of any size are found elsewhere in the vicinity, 

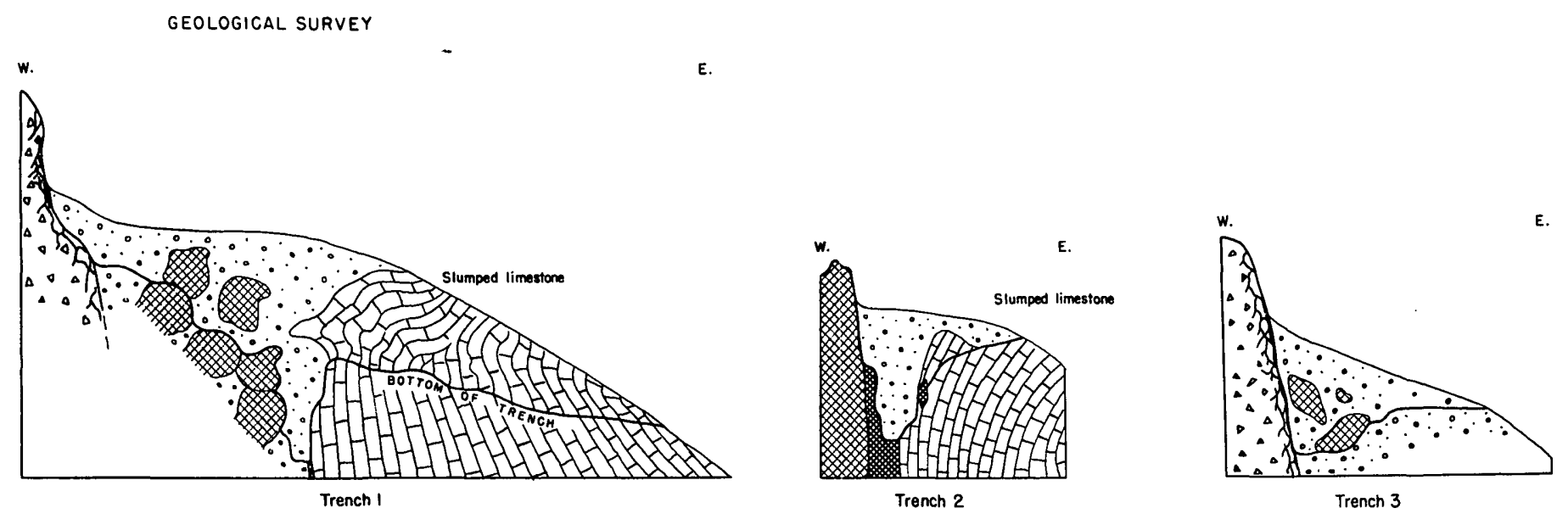

E.
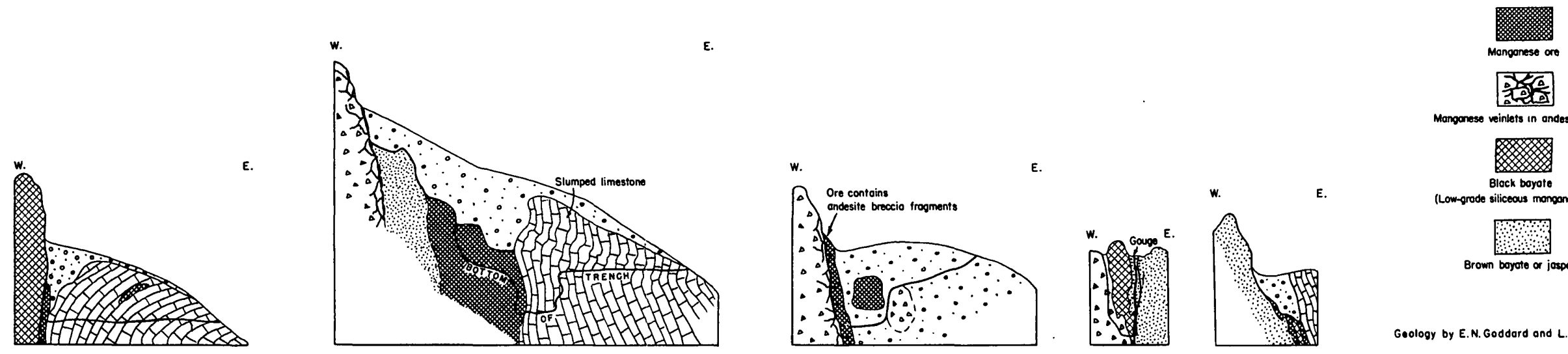

Trench 5
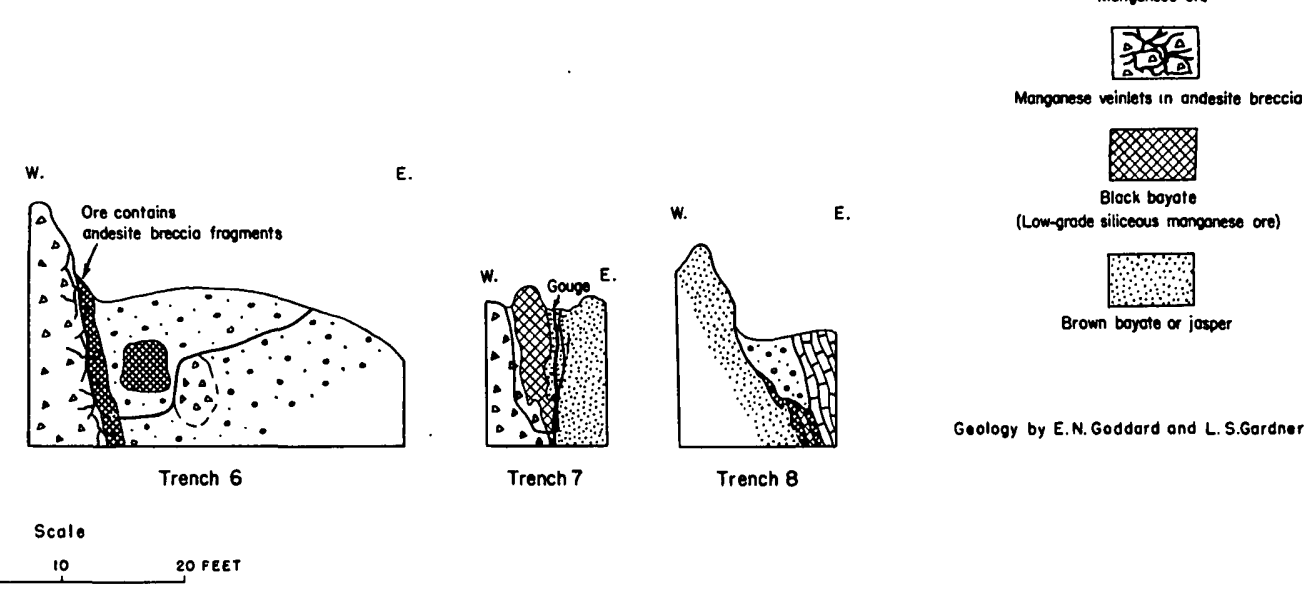

Goology by E. N. Goddard and L. S.Gordner

CROSS SECTIONS OF THE MANGANESE VEIN EXPOSED IN TRENCHES, MORNE MACAQUE MANGANESE DEPOSIT, NEAR GROS MORNE, REPUBLIC OF HAITI 
1t seems unsafe to predict any greater depth for this deposit. If, however, the ore forms a bedded deposit as the writers are inclined to belleve, it may extend to a greater depth than has been as sumed.

Table 3.-Analyses of manganese ore from the Morne Macaque manganese deposit

\begin{tabular}{l|c|c|c|c|c}
\hline $\begin{array}{c}\text { Sample } \\
\text { No. I }\end{array}$ & $\begin{array}{c}\text { Insoluble } \\
\text { in HCl }\end{array}$ & $\mathrm{Mn}$ & $\mathrm{P}_{2} \mathrm{O}_{3}$ & wO3 & $\mathrm{s}$ \\
\hline MM 1 & 17.31 & 39.00 & 0.15 & none & none \\
MM & 54.33 & 22.92 & 0.05 & do. & do. \\
MM 3 & 43.74 & 30.82 & 0.07 & do. & do. \\
MM 4 & 15.63 & 35.51 & 0.20 & do. & do. \\
MM 5 & 31.51 & 31.00 & 0.07 & do. & do. \\
MM 7 & 5.14 & 33.41 & 0.02 & do. & 0.05 \\
MM 8 & 7.85 & 40.32 & $<0.01$ & do. & trace \\
MM 9 & 15.68 & 37.19 & none & do. & trace \\
MM 10 & 40.94 & 28.16 & do. & do. & none \\
MM 12 & 11.73 & 35.89 & do. & do. & trace \\
MM 29 & 2.98 & 46.52 & $<0.01$ & do. & <0.01 \\
MM 30 & 4.69 & 47.70 & 0.01 & do. & $<0.01$ \\
\hline
\end{tabular}

MM 1 - Representative sample of 50-ton boulder at head of trench No. 1 .

MM 2 - Cut sample across 17 feet of the black bayate zone, 15 feet NW. of trench No. 1 .

MM 3 - Manganese ere selected from black bayate zone 15 feet NW. of trench No. 1 .

MM 4 - Average sample of selected float ore picked up on surface in vicinity of trench No. 1.

MM 5 - Representative sample of the less siliceous boulders in trench No. 1 .

M 7 - Sample across 2 feet of manganese ore in trench. No. 4 (includes $1 \mathrm{ft}$. of siliceous material).

MM 8 - Representative sample of large boulder in trench No. 6.

MM 9 - Sample of $1 \frac{1}{8}$ feot of ore on andesite breccia wall in trench No. 6 .

MM 10- Sample of lense of sillceous manganese ore exposed in trench No. 7 .

MM 12- Sample of 14 inches of soft ore in trench No. 8.

MM 29- Sample of 3 feet of good ore exposed in bottom of trench No. 2.

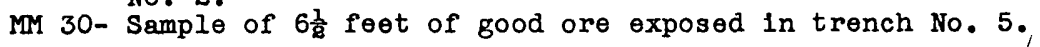

1/ Analyses d to 6 by J. G. Palrchild, U. S. Ceologicel Surreg. Analyses 7 to 12 by J. J. Fahey, U. 3. Geological Survey. Analyees 29 and 30 by V. North, U..S. Geologlcal Survey. 
the ore body showed signs of betterment, or of continuity along the bedding to greater depth. By careful management in mining, shipping, and marketing, it might be possible to mine profitabiy as much as 6,000 tons of the high-grade ore, averaging about 40 percent manganese. The low-grade sillceous or $\theta$ could not be - profitably handled by the methods available at the present time.

\section{CONCLUSIONS}

As the Morne Macaque manganese deposit is probably smald. any plan for 1ts development and exploitation must be approached with caution. On the basis of present knowledge, the expenditure of a large sum of money on such items as equipment, high-salaried personnel, and road bullding is not warranted. Early development work could be done as the trenching has been done, by a small force of hand laborers with one foreman and a man to supervise the driling of holes and blasting. If a few thousand tons of minable ore was proved by this work, and if shipping facilities and a market were available, it might be justifiable to spend a few thousand dollars in making storage bins and a dry-weather road to the property. Open cuts could probably be used in mining to a depth of 50 or 60 feet. The greater expenditures entalled by underground mining would be justified only. if at that depth 


\title{
MANGANESE PROSPECTS IN THE REGION NORTH AND NORTHWEST
}

\author{
OF JACMEL
}

By E. N. Goddard and L. S. Gardner

\section{INTRODUCTION}

In the mountainous region between Port-au-Prince and Jacmel, in the eastern part of the Southern Peninsula, is a large roughly oval-shaped area of cretaceous basaltic rocks, surrounded by upper Eocene and Oligocene limestone (see pl. 10 and fig. 4). The basalt core of the mountains forms a domal or anticlinal structure; on the north and south borders, at least, the overlying Eocene limestone dips steeply away from the basalt. In places there has been faulting of undetermined magnitude along this contact.

W. S. Burbank, 14/ wh1le making a traverse across the peninsula in 1920, found a little manganese oxide, assoclated with boulders of jaspery material, along one of these fault contacts in the valley of the Grande Riviere about 6 miles north of Jacmel. In December 1941 the writers, accompanled by Max Mangones, spent four days in the vicinity of Trouln, 12 miles northwest of Jacmel, in searching the contact of the basaltic rocks with the Eocene limestone and also the adjacent basalt area northeast of Trouln. Early in 1942 it was reported that manganese deposits had recently been discovered in the region north of Jacmel and that application for a mining concession had been filed with the Government. In view of these clrcumstances, the writers and Max Mangones visited this region in February 1942 and spent a week exploring the basalt-limestone contact and the adjacent basalt area 6 to 10 miles north of Jacmel. Octave Delauche and Léón Lamothe alded greatly in this search by guiding the party to all the known bayate and manganese localities. Many zones of the bayate boulders and a few outcrops of bayate were examined, but only a few specimens of manganese oxides were found. None of the localities held any promise of having commerical deposits of mangariese.

14/ Woodring, W. P., and others, op. Cit., pp. $475,476$. 

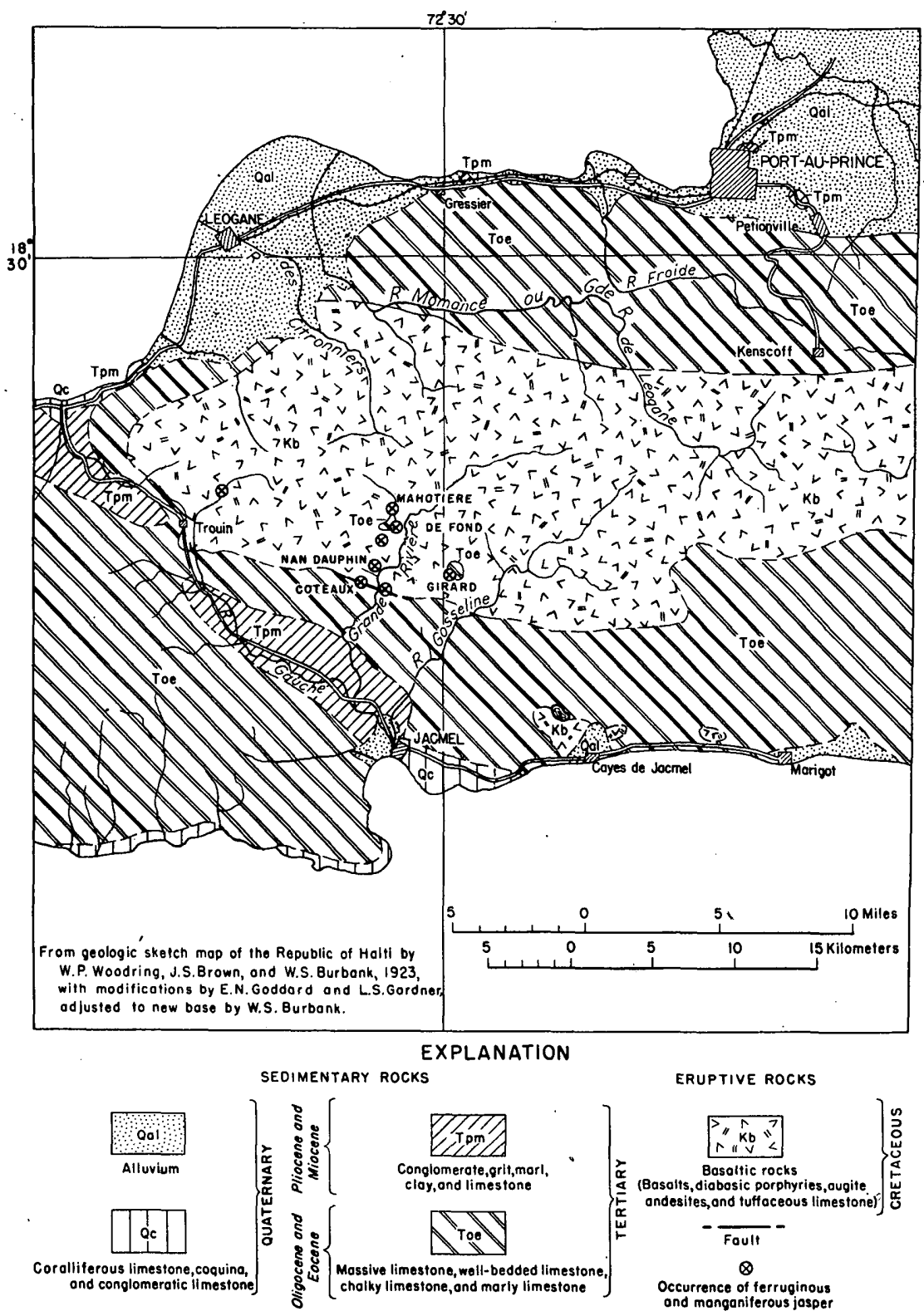

Figure 4.-Geologic reconnal esance map of the region between Port-au-Prince and Jacmel, Dépertement de l'Ouest,

Republic of Haiti. 


\section{VICINITY OF TROUIN}

In the vicinity of Trouln, the contact between the basaltic rocks and the upper Eocene Ilmestone appears to be normal and dips $55^{\circ}$ to $70^{\circ}$ or more toward the south and southwest. This contact was explored for about 2 miles southeast and $2 \frac{1}{2}$ miles northwest of Trouln. At several places along this contact large boulders of bayate have accumulated in gulches and valley bottoms, but nowhere was the bayate found in place. The boulders, some of which are much as 15 feet in diameter, are particularly numerous in the valley of the Rivière Gauche, half a mile to a nile south of Trouln. Some of them contain a few very small seams and spots of pyrolusite, but none contain any large quantity of manganese oxide. Although the bayate masses from which these boulders were derlved could not be located, the boulders are so distributed that they probably came from positions along or near the contact between the basalt and the upper Eocene limestone. The residual boulders have accumulated as a result of erosion, and have come from various levels above the present surface, but have not undergone any great amount of lateral transportation.

The valley of the Riviere Gauche also was explored for a distance of about 5 miles to the northeast and east of Trouln. This area is chiefly occupled by basalt, but in places the basalt is interbedded with thin layers of limestone, in part fossiliferous, and with thicker layers of tuff, all of which dip rather sterply to the southwest. The fossils found in these limestones are reported by Woodring 15/ to indicate a late Lower Cretaceous age. At many places within 3 miles of Trouln there are trains of bayate boulders, some of which can be traced from the river bed up to the tops of nearby low ridges. The bayate was found in place at only one locality, about 2 miles northeast of Trouln, where small Irregular masses of bayate occur along the base of a 25-foot bed of limestone interbedded with the basalt. The limestone bed was traced up the river bank to a small knob, on which a train of bayate boulders has accumulated along the border of the limestone. Some of these boulders contain a little pyrolusite, none of which, however, was found in place. The bayate outcrop is too smali to warrant any prospecting. The limestone and bayate can be traced to a point about 600 feet northwest of the knob. At this polnt the limestone is only 2 feet thick, and the bayate extends no farther.

Apparently the bayate in this region was formed in or close to the thin layers of limestones interbedded with the basalt, either by replacement of limestone or by syngenetic deposition. Manganese minerals are nowhere abundant enough to invite further exploration, and nowhere were they found in place. No bayate or manganese oxide was found to be associated with the tuff beds in the basalt rocks.

15/ Woodring, W. P., orgl comaunication. 


\section{AREA NORTH OF JACMEL}

In the area due north of Jacmel, the contact of the basalt and upper Eocene limestone has a general trend of $\mathrm{N} .70^{\circ} \mathrm{W}$. and appears to be a fault for part of its extent (see fig. 4). The basalt to the north is interbedded with numerous layers of limestone, hornstone, and tuff, and at two or more places the higher summits are capped with nearly horizontal outliers of upper Eocene Iimestone, which rest unconformably on the basalt.

The contact between the basalt and the upper Eocene limestone was explored for a distance of about 7 miles in the vicinity of the Grande Riviere and the Riviere Gosseline, and many localities in the basalt were examined, some of them as much as $3 \frac{1}{2}$ miles north of the contact. The localities visited are shown in figure 4 ; they range in altitude from about 500 to 1,800 feet.

Bayate containing very small quanities of manganese oxides was found at two places near the contact of the basalt and $11 m e-$ stone in the vicinity of the Grande Rivière. There the contact is a fault, which dips steeply to the south. On the east side of a ridge, one half to three fourths of a mile west of the Grande Rivière, three small bodies of bayate 100 to 150 feet long Ile in this fault zone, and one contains a few thin veinlets of pyrolusite. About 1,000 feet south along this ridge, there are a few other small bayate bodies in the upper Eocene limestone which alps about $30^{\circ} \mathrm{S}$, , but here the exact structural relations of the bayate to the limestone could not be determined. In on $\theta$ of these bodies a small veinlet of pyrolusite was found.

A mass of bayate about 18 feet in diameter, with some manganese stain, is exposed in the stream bed of the Grande Rivierre about where the fault should cross, but this mass is surrounded by alluvium and may not be in place. About one-fourth mile east of the river there is a more extensive bayate zone on the same fault contact. This zone gives rise to a train of bayate boulders about 100 feet wide and 400 to 500 feet long, extending along the fault line, and in a few places bayate is found in direct contact with the upper Eocene limestone. Some of the bayate boulders contain stringers and small irregular masses of manganese oxides, all of them less than an inch in width.

No bayate was found elsewhere along the contact of the basalt and IImestone. Where the contact is crossed by the Riviere Gosseline it appears to be depositional; there the upper Eocene limestone adjacent to it dips $65^{\circ} \mathrm{S}$.

In the basalt area north of the contact, drained by the Grande Rivière and the Rivière Gosseline, there are many zones and scattered concentrations of bayate boulders, but in only five of these was any manganese found. At Mahotiere, about 9 or 10 miles north of Jacmel, there are two trains of bayate boulders nearly in place; the source of one train appears to be in a tuff bed and that of the other in a limestone layer in the basalt. Neither is over 150 feet long, and the bayate contains only a few small seams and stains of manganese oxides. Float from the upper zone has piled up in a depression on the west side of a bill. Here a little bayate can be seen in place, and a few. pleces and nodules of manganese oxide can be picked up on the surface, but the surrounding bedrock is fairly well exposed and there is no room for a manganese body of appreciable size. 
South of Mahotière there are three other local1ties-at Defond, at Nan Dauphin, and at an unnamed place-where trains of bayate boulders are concentrated on weathered basalt in the vicinity of limestone beds. At each of these localities a little manganiferous material in the form of nodules and small seams is associated with the bayate, but it is insignificant in quantity and was nowhere found in place. Some bayate was found in a thin bed of limestone a few feet thick, but it contained no manganese.

At Girard, in the mountains between the Grande Rivière and the Rivière Gosseline, bayate boulders are strewn over an area about 800 feet long and 200 to 300 feet wide, and a few of them contain a very little manganese. These boulders appear to have come down the hillside from the base of a mass of, Upper Eocene limestone that overlies the basalt (see pl. 11B). No bayate or any'manganiferous material was found in place. Close to the base of the Ilmestone there are a few pleces of pinkish limestone containing pebbles of basalt and spots of manganese oxides, but these meager showings do not warrant further investigation.

In all these localities north of Jacmel the showings of manganese oxide are so poor that any further prospecting seems unjustified. In most places the boulders of bayate were not in place, having apparently accumulated from higher levels by gradual erosion of the land surface. In the few places where the bayate was found in place, it was in bodies of small size, and the geologic conditions were distinctly unfavorable for deposits of manganese ore. 



\title{
MANGANESE PROSPECTS BORDERING
}

\author{
THE MONTACNNES de la HOTTE
}

\author{
By W. S. Burbank
}

INTRODUCTION

The Montagnes de la Hotte comprise a series of high, rugged mountain ranges forming the backbone of the western part of the Southern Peninsula of Haiti (pl. 10). The central range, which trends east-west, appears to be largely composed of Cretaceous basalt, argillite, and metamorphosed limestone, and $1 \mathrm{t}$ is flanked on the north and south by ranges composed of upper Eocene limestone and younger formations. The band of Eocene and younger rocks on the north is much wider than that on the south, where the basalt series reaches the coast line near the west end of the peninsula. The basaltic core of the southern part of the range is deflected or forks southeastward beneath the western part of the Cayes plain and is exposed on the Ile à Vache. On the north side of this structural deflection and of the Cayes plain, the core of the range, which here extends from Camp Perrin nearly to Beaumont and has a width of about 6 miles, is composed of steeply dipping argililtes of Cretaceous age. In this series there are beds of limestone, but little if any coarse volcanic material and no massive flows. South of Beaumont the Cretaceous rocks are overlain unconformably by the upper. Eocene limestone. Although the extension of the argillite series westward from the road crossing the peninsula was not explored, the series presumably wedges out on the north flank of the ranges between the road and Sources Chaudes, where it is absent. No diagnostic fossils were found either in the limestones interbedded with the basalts or with the argililtes. The limestones in both series are recrystallized and strongly fractured, and are somewhat silicified but otherwise unmineralized.

Since the 1920-2l survey of the Republic of Haiti, this country has become much more accessible to travel and economic. exploitation; a search of several reported manganese localities was made early in 1942 by Woodring, Mangonès, and Burbank. A little manganese oxide was found in two places, oné north of Les Coteaux on the south coast and one east of Anse d'Hainault, but not the slightest evidence of mineralization was observed elsewhere. It is hardly possible, therefore, that the region contains any commercial deposits of manganese. 


\section{MANGANESE SHOWINGS NORTH OF LES COTEAUX}

An occurrence of manganese oxide north of Les Coteaux was brought to our attention through Inspector Camille Boncy of the Rural Agricultural School, district of Port-à-Piment. The specimens exhibited appeared to warrant examination of their source, as they showed an association of manganese oxide and tuff resembling that observed at some occurrences in Cuba. When the locality was visited, however, the average material seen in place was found to be of much lower grade than these specimens, and the mineralized area much too small to warrant trenching and sampling.

The deposit is in low basalt hills bordering the south slope of the mountains, and just back of a narrow range of coastal hills composed of upper Eocene limestone. The locality is approached by trails along a small stream valley that breaches the coastal range at Les Coteaux. It lies west of the stream and about three quarters of a mile $\mathrm{N} .35^{\circ} \mathrm{E}$. from the church in the center of the village.

The deposit is about a third of a mile from the contact between the basalt and the Eocene limestone, which strikes about N. $45^{\circ} \mathrm{W}$. and dips $35^{\circ} \mathrm{SW}$. Basalt and interbedded tuffaceous rocks that crop out on a small ridge at the manganese locality strike about N. $30^{\circ} \mathrm{W}$., and dip $50^{\circ} \mathrm{SW}$. The manganese oxide, probably mostly psilomelane, forms nodular masses, most of which are mere pellets about the size of peas and few of which are as much as an inch in diameter. These occur interstitially to, and partly enveloping, fragments of breccia near the base of a bed of calcareous tuff and breccla, and are scattered through the soll on the crest of the knoll, over an area 50 feet across and a few hundred feet in length. The nodules and pellets are so sparsely distributed, both in the soll and in the tuff-breccia that is exposed, that they can scarcely make up more than a fow percent of the rock in place. Here and there small stringers and veinlets of pyrolusite cut the more massive volcanic rocks, but they add little to the value of the deposit. Along the

- extension of the bedding to the northwest the manganese oxide disappears; where the tuff-breccla beds and basalt cut across a narrow deep ravine at the foot of the northwest slope of the hill, the rocks are weakly fractured and are stained red and green by iron minerals, but they contain no manganese oxide. Likewise in the slope facing the valley to the southeast of the knoll, there is no evidence of manganese in the rocks. No prominent structural feature is evident that might have localized the manganese, which probably was present in some form in the breccla and tuff at the time of their deposition. The veinlets of pyrolusite may have been formed by redistribution of part of this manganese, as a result of fracturing and circulation of solutions during or after the tilting of the rocks.

The basalt series was traversed for about 2 miles to the north across its strike; but no more manganese oxide was found. A few layers of hard massive limestone are interbedded with the basalt on the mountain slopes near Source Bouquet which is about 2 miles north of the locality described, but they contain no jasper and there are no indications of manganese in or near them. 


\section{LOCALITY BETWEEN CHARDONNIERES AND LES ANGLAIS}

A few large boulders of jasper contalning minor seams and stains of manganese oxide were found at a single locality about midway between the villages of Chardonnières and Les Anglais, on the south coast. The boulders have accumulated when a steep contact, probably faulted, between the basaltic rocks and the upper Eocene limestone reaches the shore. A small ravine was followed along the base of the limestone mountain that lies north of the contact, but exposures were meager and revealed only basalt in the stream bed. A few other boulders of jasper were found, but none containing manganese. This occurrence is very similar to that along the base of the upper Bocene limestone near Trouin and north of Jacmel. As several other traverses across the contacts of the same rocks, both from Port-à-Piment and at Les Coteaux, failed to reveal any appreciable quantity of manganese oxide, conditions favoring its deposition cannot be favorable in this region.

\section{LOCALITIES EAST OF ANSE D'HAINAULT}

On the new road under construction in 1942 from Anse d'Hainault to the vicinity of the agricultural plantation at sources Chaudes, a little jasper and some velnlets of manganese oxides were found. About 4 miles eagt of Anse diHainault a contact between the basalt and a body of kaolinized porphyry is exposed in a road cut. Close to this contact and on the north side of the cut is a small knoll of volcanic rock on which a few boulders of jasper have accumulated. The jasper is stained with iron but not with manganese. A single vein of manganese oxide, nowhere more than a few inches in width, is exposed in the road cut, but no other concentration of manganese was noted along the road. Bast of this cut, Iron-stained and kaolinized porphyry is exposed.for more than a mile.

Any jasper and manganese oxide that may be exposed during construction of the road will warrant attention, although here as elsewhere in the Southern Peninsula it appears unlikely that concentrations of manganese in commerical quantity will be found.

Traverses south from Sources Chaudes, extending for 6 to 7 miles across this basaltic rock, falled to reveal any manganesebearing rocks interbedded with it. At some places where manganese ore was sald to occur, the supposedly manganiferous mineral proved to be a greenish-black, lustrous varlety of chlorite-a illcate of magnesium and 1ron-associated with the basaltic rocks. Iimestones interbedded with the basaltic rocks contain neither jasper nor manganese. A few dikes of intrusive rock were seen, but the rocks in contact with them were not mineralized. 



\title{
MANGANESE AND JASPER IN THE SOUTHERN PENINSULA
}

\author{
By W. S. Burbank and E. N. Goddard
}

The distribution and mode of occurrence of the manganese oxides and associated jaspery rocks, as revealed by the deposits described above, appear to indicate a somewhat different and more complex origin than was assigned to them in the Geology of the Republic of Halti.16/ Many of the occurrences north of Jacmel lie near the contact of the upper Eocene limestone with the basalt series of Cretaceous age, or near outliers of Eocene limestone capping the older series. Some of the jasper nearly everywhere assoclated w1th the minor manganese occurrences replaces Cretaceous Iimestones; "north of Trouln and Jacmel, in the Massif de la Selle, and north of Les Coteaux in the Massif de la Hotte, evidence of replacement or assoclation with Cretaceous beds is definitely established. Jasper occurs, also, in obscure contact with the basal beds of the upper Eocene limestone, but few if any examples of replacement of the Eocene limestone by menganiferous or jaspery materlal were found. The accumulations of jaspery materlal near the contacts of the Cretaceous and Bocene rocks, or in Cretaceous rocks not far below this contact, may indicate that the jasper was formed during both cretaceous and early Tertiary time, and some of it may be related in origin to the surface on whlch the Bocene limestones were deposited. Longcontinued erosion of this old land surface may have resulted in the destruction of many of the later volcanlc accumulations, together with any deposits of manganese and fasper that may have been assoclated with them. Remnants of the jasper may have accumulated here and there on this land surface, much as they have on the present surface, and have since been uncovered by erosion. Such examples are perhaps represented by the occurrences near Girard and at the base of the Bocene near Trouln. The deposits in place in the Cretaceous rocks mey represent similar, more widespread deposits of late Cretaceous age.

It is belleved that the materials composing the deposits were derived from the volcanic rocks. Ground waters, perhaps locally heated and acldifled by volcanlc activity, may have traversed porous or fissured rocks, leaching out the slilca, manganese, and Iron, which were later deposited when the charged waters came into contact with calcareous rocks or other precipltating agents. A simliar origin has been inferred for small deposits of manganese oxide and manganiferous jasper assoclated with volcanic rocks in Colorado, in the westerm United States.

26/ Woodring, W. P., and othere, op. e1t., pp. 473-477 (Fronch odition, pp. 534-538). 
The ores of Cuba also resemble the occurrences in Haiti in their. local association with jasper (bayate) and in certain aspects of mineralogy. Their origin has recently been sumarized, by Park 17/ as follows:

"The manganese is thought to have been deposited by warm springs which were active during the last stages of Eocene volcanism that centered in the Sierra Maestra. Textural features show that the manganese oxides were in part deposited in open spaces-conduits of spring waters and pore spaces of the rocksand in part by replacement of the rocks. Some of the deposits are bedded and appear to be primary accumulations of manganese oxides, presumably derived from spring waters discharged into the sea. The lithologic character of the bedded deposits indicates that they were deposited contemporaneously with the associated sedimentary rocks."

It is probable that the Cuban and Haltian deposits are of very similar origin, but that the conditions of accumulation in the Southern Peninsula of Hait1 were much less favorable for large deposits than those existing in the Cuban province during early Tertlary time. The massive lava flows and coarse brecclas of Cretaceous age in Hait1 differ considerably from the uniformly bedded and finer-grained tuffs and brecclas of Eocene age in Cuba. Tuffs form a considerable part of the upper Eocene rocks of Cuba, but are absent or obscure in the upper Eocene of Haiti. Hence the rocks of Ha1t1 neither constitute as good sources of manganese as those of Cuba nor afford the widespread porous layers required for its effective deposition. The scattered, small, and pockety character of the Haitian deposits, in so far as they are preserved on the Southern Peninsula, thus appears to be a consequence of the general nature and history of the enclosing rocks, rather than of significant differences from the Cuban deposits in mode of origin.

17/ Park, C. P., Jr., Manganose deposite of Cuba: J. S. Cool. Survey Bull. $935-B$, p. 75, 1942 . 